\title{
Acute Diarrhea and Types of Dehydration in Libyan Children
}

\author{
Aisha A Sehari ${ }^{1 *}$, Abdulrahman Ali Baitalmal ${ }^{1}$ and Ashraf M Ayad ${ }^{2}$ \\ ${ }^{1}$ Tripoli University, Faculty of Medicine, Tripoli, Libya \\ ${ }^{2}$ Damanhour Medical institute, Egypt \\ *Corresponding Author: Aisha A Sehari, Tripoli University, Faculty of Medicine, \\ Tripoli, Libya.
}

Received: February 20, 2021

Published: March 29, 2021

(C) All rights are reserved by Aisha A Sehari., et al.

\begin{abstract}
Acute diarrhea is a leading cause of illness in developing countries. About seventeen of per cent Libyan children suffer from diarrhea. Diarrhea causes about $12 \%$ of mortalities in children aged 0 - 5 years. The aim of this study is to estimate to estimate the types and the degree of dehydration and to find out the correlation between types and degree of dehydration and contributing risk factors. Seasonal variations were studied also. A retrospective study was done on all children patients admitted to Tripoli pediatric hospital during the year 2006 (from 01/01/2006 to 31/12/2006) complaining of acute diarrheal diseases, age group (one month to 60 months), with exclusion of bloody diarrhea. All the cases were evaluated for their clinical presentation and laboratory results. The results of the study was summarized as following: total were 675 admitted patients diagnosed as acute diarrhea which was (14.91\%) out of the total admission (4526 patients) to this hospital during that year. 408 males, accounts for (60.44\%), females were 267 patients (39.56\%). Moderate dehydration was the commonest type of dehydration (374 patients $=55.44 \%$ ), followed by severe type $(239$ child $=35.4 \%)$ the least was mild dehydration ( 62 patients $=9.2 \%$ ). Regarding the types of dehydration isonatremic dehydration was the commonest ( 458 patients $67.85 \%$ ), followed by hypertonic dehydration (121 patients $=17.93 \%$ ), the least was hyponatremic type (96 patients $=14.22 \%$ ). Out of these children patients 8 children died $(1.19 \%)$ due to complication of acute diarrhea except one child who got other major contributing cause of mortality. The peak of the acute diarrheal disease in this studied group was during winter and spring (months $2,3,4$ ), total patients were (276 child 40.89\%), Low incidence was reported during summer and early autumn (113 child $16.74 \%)$.
\end{abstract}

So, we can conclude from our study that acute diarrheal diseases is a common problem and a common cause of emergency admission to hospitals, especially those with moderate isotonic dehydration followed by severe isotonic type. Mild hypernatremic dehydration was the least. Dehydration is a major risk factor especially in association with other significant illness. A lower incidence of hypertonic dehydration was reported in this study compared with our previous one.

We recommend that more orientation about mild hypertonic dehydration clinically.

Further studies are required to identify the etiologies of diarrhea in Libyan children especially during the peak seasons and their complications.

The value of ROTA virus vaccination is still to be further evaluated by multicentre studies.

Keywords: Acute Gastroenteritis; Dehydration; Risk Factors

\section{Introduction}

Worldwide there are an estimated one billion episodes of and 3.3 million deaths due to diarrhea each year among children aged less than 5 years. In the developed world gastroenteritis is common and usually mild but should not be underestimated [1]. Acute infantile diarrhea are mostly caused by microbial organisms. Im- portant causes are viruses, bacteria, protozoa. The five common organisms most frequently associated with diarrhea increase motility especially in in young children are: Rota virus, ETEC, Shigella, Campylobacter jejuni and Cryptosporidium. In 20 - 30\% of diarrheal cases, no specific pathogens could be identified, while in the other $75 \%$ of cases of infective diarrhea a pathogen can be identified 
in the stool when all available diagnostic methods are used [1,2]. Other causes of diarrhea include: Lactose intolerance. Feeding problems. Formula fed infants. Weaning feeds, exposure to insecticides and heavy metallic poisoning. Diarrhea present with other infections elsewhere in the body e.g. pneumonia or otitis media. the mechanism of which is still obscure. primary mechanism in pathogenesis of diarrhea could be secretory, osmotic, decrease surface area, increase motility and mucosal invasion. The mechanisms of diarrhea differ with the infective agent. The organism may Invade the mucosa, causing inflammation of the lamina, produce cytotoxins that disrupt cell function and protein synthesis, secrete an enterotoxin that alters cellular salt and water balance yet leaves the cell morphology undisturbed. Adherence to the mucosal surface, disrupting normal cell function [3]. About $75 \%$ of fluid ingested, which includes the gastric, pancreaticobiliary and intestinal secretions, is reabsorbed by the small intestine and about $24 \%$ by the large intestine. Primary absorption of water in the small intestine is done in the tip cells of the microvilli. This is an active process using sodium-glucose and sodium-amino acid transporters. Sodium and chloride ions are exchanged actively for hydrogen and bicarbonate ions, maintaining both electro neutrality and $\mathrm{pH}$ homeostasis. An active intracellular pumps then pumps the excess sodium into the blood stream and the chloride back into the lumen $[3,4]$. It is estimated that diarrhea is responsible for about four million deaths each year largely amongst children less than two years old. Death occurred mainly due to the gross defects in diagnosis and management of complications $[5,6]$. Dehydration is caused by the loss of water and electrolytes in the liquid stool and vomits'. Fever can cause an additional loss of water. Dehydration can lead to hypovolemia, cardiovascular collapse, and death if not treated promptly $[5,7]$. Due to clinical signs dehydration is classified to mild, moderate or severe. Type of dehydration depends on WHO chart which is shown in figure.

\section{Assessment of Dehydration}

\begin{tabular}{|c|c|c|c|}
\hline & $\begin{array}{l}\text { No signs of } \\
\text { dehydration }\end{array}$ & $\begin{array}{l}\text { Some (mod.) } \\
\text { dehydration }\end{array}$ & \begin{tabular}{|c} 
Severe \\
dehydration
\end{tabular} \\
\hline $\begin{array}{l}\text { General } \\
\text { condition }\end{array}$ & $\begin{array}{l}\text { well, } \\
\text { alert }\end{array}$ & $\begin{array}{l}\text { restless, } \\
\text { irritable }\end{array}$ & $\begin{array}{l}\text { lethargic, } \\
\text { unconscious }\end{array}$ \\
\hline E Eyes & normal & sunken & sunken \\
\hline M $\begin{array}{l}\text { Mouth \& } \\
\text { Drinking }\end{array}$ & normal & $\begin{array}{l}\text { thirsty, drink } \\
\text { eagerly }\end{array}$ & $\begin{array}{l}\text { poor or una- } \\
\text { ble to drink }\end{array}$ \\
\hline$S^{\text {Skin pinch }}$ & retums rapidly & returns slowly & very slowly \\
\hline \multicolumn{4}{|c|}{ Always start from Red Column } \\
\hline
\end{tabular}

Figure
Isotonic, hypertonic (hypernatremic) or Hypotonic (Hyponatremic) depends on serum sodium result normal range (130 - 150 $\mathrm{mEq} / \mathrm{L}$ ) [2]. Hypokalemia means serum potassium less than 3.5 $\mathrm{mEq} / \mathrm{L}$. It is a common finding in acute infantile diarrhea due to excessive potassium loss in stool and acidosis [8]. Metabolic acidosis (Base-deficit acidosis) is another complication, every dehydrated case is potentially acidotic. Seizures do complicate diarrhea and dehydration due to metabolic disturbance, fever and systemic upset [9-11]. Gastrointestinal complications also occur such as secondary carbohydrate malabsorption or intolerance, protein intolerance and protein losing enteropathy, persistent diarrhea pseudomembranous colitis may complicate antibiotics particularly neomycin, intestinal perforation and toxic mega colon may complicate shigella [3]. Rectal prolapse can complicate shigellosis and chronic diarrhea in wasted children. A very close interaction exists between diarrhea and malnutrition. Persistent diarrhea or repeated attacks of acute diarrhea can lead to or aggravate malnutrition. This is because nutrient requirements are increased during diarrhea (as in any other infection) whereas nutrient intake and absorption are usually decreased due to vomiting and unnecessary dietary restrictions. Malnutrition also contributes substantially to the problem of diarrhea. The incidence of diarrhea in severely malnourished children is threefold that in well nourished children. Moreover, diarrhea in malnourished children runs a more severe and longer lasting course with more risk of complications and higher (fourfold) mortality [1-3]. Disseminated intravascular coagulation (DIC): Which is supposed to be precipitated by acidosis, hemoconcentration and possibly by endothelial damage (vasculitis) is another complication of acute gastroenteritis, there may be a widespread thrombosis affecting especially the lungs and kidneys. Clinically, DIC presents with bleeding tendency together with cutaneous tissues [12]. Treatment of acute diarrheal disease depends on early diagnosis and proper fluid therapy either orally using ORS or through intravenous line with proper fluid.

\section{Materials and Methods}

This study was conducted on Libyan children admitted to Algala-children (Teaching-Hospital) in Tripoli during from 1/1/2006 to $31 / 12 / 2006$

The study was designed to study three groups of children:

- Group I: Mildly dehydrated children.

- Group II: Moderately dehydrated children

- Group III: Severely dehydrated children.

The cases were selected to fulfil the following criteria:

Inclusion criteria:

- Age range: $\geq$ one month to $\leq 60$ months. 
- Complaint: Acute diarrhea for $2-3$ and $\leq 14$ days duration with or without vomiting.

- $\quad$ Degree of dehydration: Mild, moderate and severe grades.

\section{Exclusion criteria:}

- Children with overt signs of severe protein calorie malnutrition.

- Children with bloody diarrhea.

All cases were subjected to the following discussed below.

Clinical evaluation: *Detailed history taking and a full clinical examination degree of dehydration, presence of malnutrition, severe infection and place of living, housing water supply.

Assessment of dehydration [3]

\begin{tabular}{|c|c|c|c|}
\hline & & $\begin{array}{l}\text { Dehydration } \\
\text { (loss in body } \\
\text { weight, \%) }\end{array}$ & \\
\hline & $\begin{array}{c}\text { Mild } \\
(<5 \%)\end{array}$ & $\begin{array}{c}\text { Moderate } \\
(5-9 \%)\end{array}$ & Severe $(>10 \%)$ \\
\hline Heart rate & Normal & Increased & $\begin{array}{l}\text { Tachycardia/ } \\
\text { bradycardia in pre } \\
\text { arrest situation }\end{array}$ \\
\hline $\begin{array}{l}\text { Blood pres- } \\
\text { sure }\end{array}$ & Normal & $\begin{array}{l}\text { Normal or } \\
\text { reduced }\end{array}$ & Greatly reduced \\
\hline Skin & Normal & $\begin{array}{l}\text { Decreased } \\
\text { turgor }\end{array}$ & Decreased turgor \\
\hline Fontanelle & Normal & $\begin{array}{c}\text { Normal slightly } \\
\text { depressed }\end{array}$ & Sunken \\
\hline $\begin{array}{l}\text { Mucous } \\
\text { membrane }\end{array}$ & $\begin{array}{l}\text { Slightly } \\
\text { dry }\end{array}$ & Dry & Dry \\
\hline Extremities & Perfused & $\begin{array}{l}\text { Delayed capil- } \\
\text { lary refill }\end{array}$ & Cool, mottled \\
\hline $\begin{array}{l}\text { Mental } \\
\text { status }\end{array}$ & Normal & $\begin{array}{l}\text { Normal or } \\
\text { lethargic }\end{array}$ & Lethargy, coma \\
\hline $\begin{array}{l}\text { Urine out- } \\
\text { put }\end{array}$ & $\begin{array}{c}\text { Slightly } \\
\text { decreased }\end{array}$ & Decreased & Absent \\
\hline Thirst & $\begin{array}{c}\text { Slightly } \\
\text { increased }\end{array}$ & Increased & Greatly increased \\
\hline
\end{tabular}

\section{Laboratory evaluation}

All groups (dehydrated and control) were subjected to the following investigations before the start of either ORS or infusion therapy for the dehydrated groups:

1. Serum electrolytes and acid-base profile:

a. Serum sodium and potassium by stat/ion system made by technicom [8]. b. Blood $\mathrm{pH}$ and bicarbonate by ABL2, Acid base laboratory [9].

c. Complete blood picture including, platelets count by coulter method [16].

d. Random blood sugar [17].

e. Blood urea [18].

\section{Results}

Total admitted patients diagnosed as acute diarrhea were 675, which accounts (14.91\%) out of the total admission (4526 patients) to this hospital during that year as shown in figure 1.

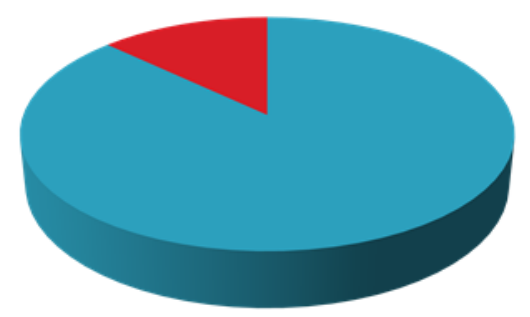

Figure 1: Distribution of gastroenteritis (GE) patients among the total admitted children.

Regarding gender 408 child were males which accounts for $(60.44 \%)$ while females were 267 patients which correlate to $(39.56 \%)$ as shown in figure 2 .

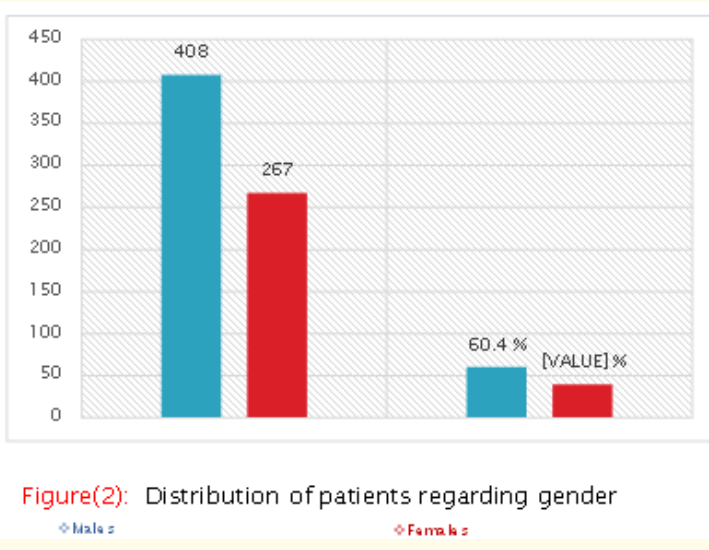

Figure 2: Distribution of patients regarding gender. 
Moderate dehydration was the commonest type of dehydration $(374$ patients $=55.44 \%)$, followed by severe type $(239$ child $=35.4 \%$ ) the least was mild dehydration ( 62 patients $=9.2 \%)$ as shown in figure 3.

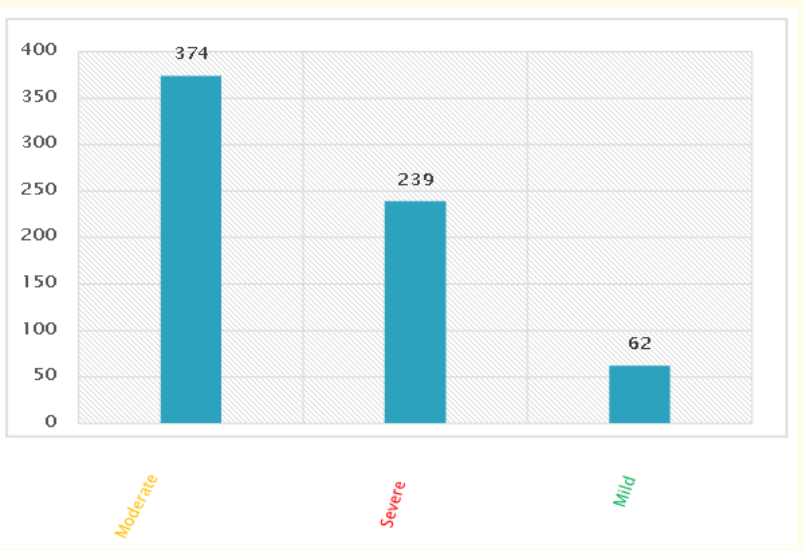

Figure 3: Distribution of degrees of dehydration among studied children.

Regarding the types of dehydration isonatremic dehydration was the commonest ( 458 patients $67.85 \%$ ), followed by hypertonic dehydration (121patients $=17.93 \%)$, the least was hyponatremic type (96 patients $=14.22 \%$ ) as shown in figure 4 .

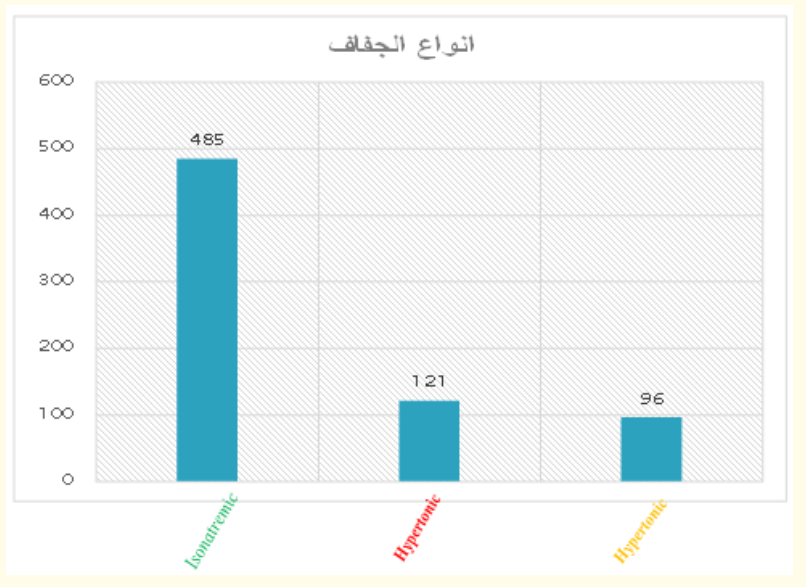

Figure 4: Types of dehydration.

Out of these children patients 8 children died (1.19\%) due to complication of acute diarrhea except one child who got other major contributing cause of mortality. The peak of the acute diarrheal disease in this studied group was during winter and spring (months $2,3,4$ ), total patients were (276 child 40.89\%), low inci- dence was reported during summer and early autumn (113 child $16.74 \%)$.

\section{Discussion}

The present study had been conducted on 675 Libyan children suffering of acute diarrhea with (374) moderately dehydrated child, severe dehydrated children were (239) and mildly dehydrated children were the least 62 patients. They were investigated for electrolytes profile, some metabolic, haematological changes before the start of either oral or infusion therapy.

Isonatremic dehydration was the commonest (458 patients $67.85 \%$ ), followed by hypertonic dehydration the least was hyponatremic type (96 patients $=14.22 \%$ ). The serum sodium was higher in 121 dehydrated child which account to $17.93 \%$. Hypernatremia was reported in Libyan children ( $<5$ years) to be $10 \%$ in Bengazi [17] and 2\% in Algala Hospital [18]. Higher percentage of hypernatremia was reported 1999 (41\%) in a sample of Libyan children.

The slightly higher percentage of hypernatremia among Libyan infants in the present work, compared to international value (15\%), it may be attributed to the following possibilities:

a. High salt load of the under water resources mentioned by some references [7]. Although, the complete chemical analysis of water samples derived from 4 different areas in Libya were found to be suitable for drinking.

b. The usual ORS sodium content seems to be invalid for Libyan circumstances and a low sodium ORS should be carried out.

The hazard of hyperconcentrated ORS is found to be $13 \%$ of the according to ALMCHS.

Mean serum potassium was significantly higher among moderately dehydrate infants when matched with both mild and severely dehydrated cases. The rise of potassium fall within the normal range (3.5 - $5.5 \mathrm{mEq} / \mathrm{L})$.

However, hyperpotassium ( $>5.5 \mathrm{mEq} / \mathrm{L}$ ) was obtained in some cases in the present work This finding could be attributed to hemoconcentration, intracellular shift of excess hydrogen ions replacing the intracellular potassium and lastly due to prerenal failure (hypoperfused kidneys in dehydration). On the other hand hypopotassemia was detected in some cases $(<3.5 \mathrm{mEq} / \mathrm{L})$ in the present work. It seems that the potassium loss in diarrheal stools had exceed the previously mentioned factors that augment potassium in the serum of the dehydrated cases [2]. 
Acidosis $(\mathrm{pH}<7.33)$ was detected in all severely dehydrated patients and in some cases out of children with moderate the present work. Usually every dehydrated case is considered potentially acidotic by different investigations.

\section{Conclusion}

So, we can conclude from our study that acute diarrheal diseases is

- A common problem and a common cause of emergency admission to hospitals, especially those with moderate isotonic dehydration followed by severe isotonic type.

- Mild hypernatremic dehydration was the least.

- Dehydration is a major risk factor especially in association with other significant illness.

- A lower incidence of hypertonic dehydration was reported in this study compared with our previous one.

- we recommend that more orientation about mild hypertonic dehydration clinically.

- Further studies are required to identify the etiologies of diarrhea in Libyan children especially during the peak seasons and their complications.

\section{Recommendation}

- We recommend that more orientation about mild hypertonic dehydration clinically.

- Further studies are required to identify the etiologies of diarrhea in Libyan children especially during the peak seasons and their complications.

- The value of ROTA virus vaccination is still to be further evaluated by multicentre studies.

\section{Bibliography}

1. Professor Ahamed A Madkour. "Diarrhea Essential of paediatrics”. Alexandria university Paed. Department (1998): 123127.

2. Sperling MA. "Diarrhea and diarrhea in developing countries: Pehramn R, Kliegman R, Nelson W, Vaugha V, eds. Nelson Text book of paediatric $21^{\text {st }}$ edition Philadelphia, WB Saunders Company 2 (2019).

3. Ministry of health Control of diarrheal disease NCDDF, world health organization (WHO). United nations, children Fund (UNICEF) control of diarreal disease. NCDP (2019).

4. ARAB Libyan Maternal and Child Health Survey, League of Arabs States 1996 (1997).

5. Laurence J. "Logan Haemostasis and Bleeding disorders". In: Josoph, J. Mazza, eds. Manual of clinical haematology. Bslon: Little Brown company (1998): 285-314.
6. Nathan and Oski's. "Hematology of infancy and childhood". $5^{\text {th }}$ edition, W.B. Saunders company, (2000): 1682-1683.

7. McGrath JM and Stewart GJ. "The effects of endotoxin on vascular edothelium". Journal of Experimental Medicine 129 (1969): 83.

8. Pankow-Prandota L., et al. "The haemostasis system in toxic infantile diarrhea". Ped PoI 57 (1982): 503-509.

9. Practical Haematology, by sir John V. Dacie MD. (London) RCP (Lond) FRCpath FRS. And S.M. Lewis Bs. MD (Capetown DCP (Lond). FRCpath, 6 ${ }^{\text {th }}$ edition (1994): 239.

10. The evolution of therapy for dehydration: should deficit therapy still be taught?" Pediatrics 98 (1996): 171-177.

11. Freedman SB., et al. "Prospective assessment of practice pattern variations in the treatment of pediatric gastroenteritis". Pediatrics 127 (2011): e287-295.

12. Sharp AA. "Diagnosis and management of DIC". British Medical Bulletin 33 (1978): 265-272.

13. Fernandes FJ and Kahn HD. "Determination of serum Sodium and potassium". Clinical Chemistry 24 (1991): 230-233.

14. Siggard OA. "An Acid-base chart for arterial blood with normal and pathological reference areas". Scandinavian Journal of Clinical and Laboratory Investigation 27 (1971): 239-245.

15. Coulter Electronic Inc., Hialeah. Fla. 33\% and Missinssanga. Ontario.

16. KM An 0." Louchine method for body-fluid glucose determination-clin". Chem 8 215-1962.

17. Ratan S., et al. "A family health survey for diarrheal diseases and EPI coverage at Al-Abear, Benghazi-Libya". Alexandria Journal of Pediatrics 4.343 (1990): 440.

18. BEN Halim MM. "Gastroentestinal in Tripoli children Hospital. Analysis of 1249 Hospital Admissions". Alfateh University, Libya (1991).

\section{Assets from publication with us}

- Prompt Acknowledgement after receiving the article

- Thorough Double blinded peer review

- Rapid Publication

- Issue of Publication Certificate

- High visibility of your Published work

Website: www.actascientific.com/

Submit Article: www.actascientific.com/submission.php

Email us: editor@actascientific.com

Contact us: +919182824667 